\title{
Structural Biology of Disease-Associated Title: Repetitive DNA Sequences and Protein-DNA Complexes Involved in DNA Damage and Repair
}

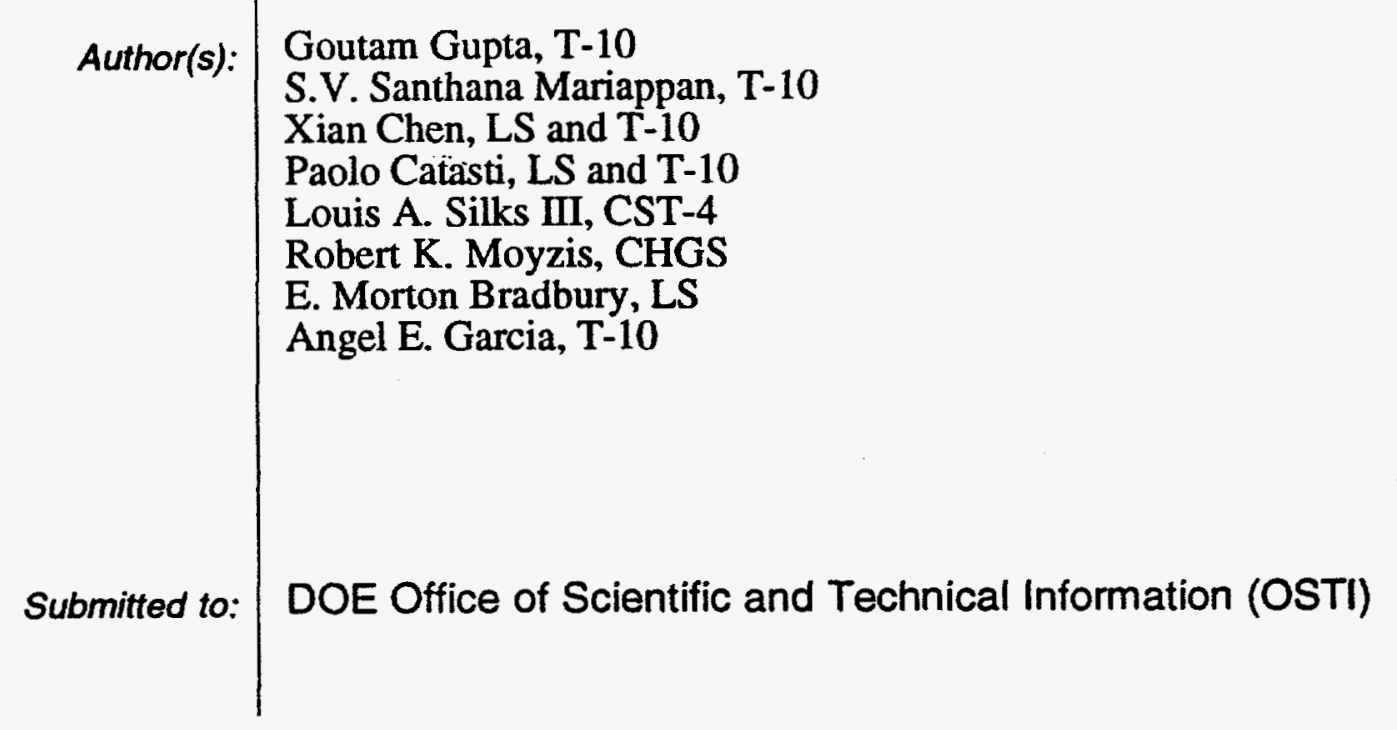

DISCLAIMER

\begin{abstract}
This report was prepared as an account of work sponsored by an agency of the United States Government. Neither the United States Government nor any agency thereof, nor any of their employees, makes any warranty, express or implied, or assumes any legal liability or responsibility for the accuracy, completeness, or usefulness of any information, apparatus, product, or process disclosed, or represents that its use would not infringe privately owned rights. Reference herein to any specific commercial product, process, or service by trade name, trademark, manufacturer, or otherwise does not necessarily constitute or imply its endorsement, recommendation, or favoring by the United States Government or any agency thereof. The views and opinions of authors expressed herein do not necessarily state or reflect those of the United States Government or any agency thereof.
\end{abstract}

\section{DISTRIBUTION OF THIS DOCUMENT IS UNLIMITED}

Los Alamos National Laboratory, an affimattve action/equal oppontunity employer, is operated by the University of Callomia tor the U.S. Depariment of Energy under contract W-7405-ENG-36. By acceptance of this article, the publisher recognizes that the U.S. Govermment retains a nonexclustve, royaliyfree license to publish or reproduce the published form of this contribution, or to allow others to do so, for U.S. Govemment purposes. Los Alamos National free license to publish or reproduce the published form of this contribution, or to allow others to do so, for U.S. Govemment pumoses. Los Alamos National Laboratory strongly supports academic freedom and a researcher's night to publish; as an hstitution, however, the Laboratory does not endorse the viewpoint of a pubilication or guarantes its technical correctness. 


\section{DISCLAMMER}

Portions of this document may be illegible in electronic image products. Images are produced from the best available original document. 


\section{Structural Biology of Disease-Associated Repetitive DNA Sequences and Protein-DNA Complexes Involved in DNA Damage and Repair}

Goutam Gupta* (T-10), S.V. Santhana Mariappan (T-10), Xian Chen (LS, T-10), Paolo Catasti (LS, T-10), Louis A. Silks III (CST-4), Robert K. Moyzis (CHGS), E. Morton Bradbury (LS) and Angel E. Garcia (T-10)

\section{Introduction}

This is the final report of a one-year, Laborastory-Directed Research and

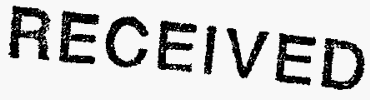

\section{JUL 251997}

Development (LDRD) project at the Los Alamos National Laboratory (LANL). Within the next decade, it is anticipated that the complete DNA sequences of the human and several model organisms will be determined and will be available for comprehensive analysis. The next challenge lies in systematically deciphering the roles of coding and regulatory (upstream, downstream, intron) regions of genes. Of particular importance are the microsatellites in the regulatory regions of genes. The current project is aimed at formulating the sequence-structure-function correlations of various microsatellites in the human (and other eukaryotic) genomes. Here we have been able to develop and apply structure biology tools to understand the following:

- the molecular mechanism of length polymorphism microsatellites,

- the molecular mechanism by which the microsatellites in the noncoding regions alter the regulation of the associated gene, and finally

- the molecular mechanism by which the expansion of these microsatellites impairs gene expression and causes the disease.

Our multidisciplinary structural biology approach is quantitative and can be applied to all coding and noncoding DNA sequences associated with any gene. Both NIH and DOE are interested in developing quantitative tools for understanding the function of various human genes for prevention against diseases caused by genetic and environmental effects.

\footnotetext{
*Principal Investigator, e-mail: gxg@lanl.gov
} 


\section{Structural Studies on the FraX, DM, and HD Triplet Repeats}

Microsatellites interspersed, throughout the human genome, are tandem repeats of 2-7 base-pairs [1-4]. Although, microsatellites are most frequently present in the noncoding region of a gene, at times they are located inside the coding sequence of a gene. Microsatellites have generated a great deal of research interests due to their involvement with many genetically inherited diseases. For example, the microsatellites of the GC-rich DNA triplets are associated with fragile $X$ syndrome (FraX), myotonic dystrophy (DM), and Huntington's disease (HD) [5-7]. The common genetic cause of FraX, DM, and HD is the inherent genetic instability of the DNA triplet repeat associated with the disease in question, i.e., the GC-rich triplet repeats exhibit variation in their repeat length (or length polymorphism). Repeat lengths are typically short $(n<50)$ in normal phenotypes but disease phenotypes show massive expansion $(n>100)$ in repeat length. This expansion leads to anomalous gene expression and the onset and progression of the disease. In this project, we have carried out structural biology research to establish the molecular basis of FraX, DM, and $\mathrm{HD}$. We tried to answer the following questions:

(i) Why are (CCG)n, (CTG)n, (CAG)n, the three triplet repeats associated respectively with FraX, DM, and HD, so susceptible to variations in repeat length, $n$ ?

(ii) How does this length variation affect the expression of the associated gene?

The answer to the first question (or the observed length polymorphism) is due to the ability of these repeats to form hairpin structures. We have used high resolution NMR spectroscopy to determine the detailed structures and dynamics of these hairpins [8-15]. We have also shown by an in vitro M13 replication assay that the same hairpin structures can be formed during the replication of these repeat sequences. Hairpin formation should lead to slippage during replication and the observed length polymorphism (i.e., hairpin formation in the growing chain should cause expansion whereas hairpin formation in the template should cause deletion).

The answer to the second question (i.e., the effect of length polymorphism on gene expression) will depend upon the location of the triplet repeat with respect to the associated gene [see Figure 1]. If the triplet repeat is located inside the coding sequence (as (CAG)n in HD), length polymorphism should cause altered length of a poly-aminoacid tract in the gene product which may disable or interfere with the normal function of the gene product. When triplet repeats are located upstream of a gene (as (CCG)n in Frax) in normal phenotypes with $\mathrm{n}<50$, they may exert regulatory role in transcription due to their ability to form hairpin structures close to the transcription start site (TSS). However, the same hairpins (especially in the case of (CCG)n in Frax) are also susceptible to CpG 
methylation. And the longer the (CCG)n repeat, the higher is the probability of CpG methylation. Therefore in disease phenotypes of Frax with $n>200$, extensive CpG methylation causes suppression of the fragile $X$ mental retardation 1 (FMR-1) gene.

In Figure 2, we postulate the mechanism of the suppression of the FMR-1 gene that causes Frax. The key to our mechanism is the formation of a three-way junction with a (CCG)n hairpin and two Watson-Crick arms. The presence of $\mathrm{C}^{\cdot} \mathrm{C}$ pairs in the (CCG)n hairpin and the slipping and sliding motion of this hairpin makes the three-way junction an excellent substrate for methylation by the human methyl transferase, the enzyme that methylates the CpG sites in the humam DNA (for details see publications 1-4; this work has also been reviewed in the J. of NIH Research, 1995). Our model in Figure 2 is consistent with the published genetic and biochemical data [16-17].

In DM, the (CTG)n triplets are located downstream of the DM protein kinase (DMPK) gene. Formation of a few well-positioned (CTG)n mRNA hairpins following the stop codon of the DMPK gene ensures efficient termination of transcription, processing and export of mRNA. When the (CTG)n repeats are expanded $(n>50)$ in disease DM phenotypes, the hairpins are spread over a long length beyond the stop codon. This diminishes (and abrogates) the effectiveness of the (CTG)n hairpins in gene expression. 


\section{Publications}

1. Hairpins are formed by the single DNA strands of the Fragile $X$ Triplet Repeats:

Structure and Biological Implications. Chen, X., Mariappan, S.V.S., Catasti, P., Ratliff, R., Moyzis, R.K., Laayoun, A., Smith, S.S., Bradbury, E.M., and Gupta, G. Proc. Natl. Acad. Sci. USA (1995) 92:5199-5203.

2. Solution Structure of the Individual Strands of the Fragile $X$ repeat. Mariappan, S.V.S., Chen, X., Catasti, P., Ratliff, R., Moyzis, R.K., Bradbury, E.M., and Gupta, G. (1996) Nucl. Acid Res. 24:784-792.

3. Hairpin and junction structures of fragile $X$ triplets. Mariappan, S.V.S., Chen, X., Catasti, P., Ratliff, R., Moyzis, R.K., Laayoun, A., Smith, S.S., Bradbury, E.M., and Gupta, G. Biol. Str. \& Dyn. Proc. of the 9th Conversation in Biomol. Stereodyn., SUNY at Albany, NY 1995, Eds. Sarma, R.H. and Sarma, M.H., Adenine press, pp 105119.

4. Hairpin Induced Slippage and Methylation of the Fragile X Repeats. Chen, X., Mariappan, S.V.S., Smith, S., Ratliff, R., Moyzis, R.K., Bradbury, E.M. and Gupta. G. J. Biomol. Str. \& Dyn. (1997) (in press).

5. Solution Structure of the DNA Triplet, CAG, Associated with Hunitington's Disease. Mariappan, S.V.S., Silks, L.A., Springer, P.A., Wu, R., Chen, X., Moyzis, R.K., Bradbury, E.M., Garcia, A.E., and Gupta, G. (1997). . J. Biomol. Str. \& Dyn., in press. 


\section{References}

1. Moyzis, R. K., Torney, D. C., Meyne, J., Buckingham. J. M., Wu, J. -R., Burks, C., Sirotkin, K. M., and Goad, W. B. (1989). The Distribution of Interspersed Repetitive DNA Sequences in the Human Genome. Gen. 4:273-289.

2. Stallings, R. L., Torney, D.C., Hildebrand, C. E., Longmire, J.L., Deaven, L.L., Jett, J. H., Doggett, N.A., and Moyzis, R.K. (1990). Physical mapping of human chromosomes by repetitive sequence fingerprinting. PNAS USA, 87: 6218-6222.

3. Richard, R.I. and Sutheriand G.R. (1994). Simple repeat DNA is not replicated simply. Nature Genetics, 6: 114-116.

4. Dover, G. (1995) Slippery DNA runs on and on and on... Nature Genetics, 10, 254256.

5. Richards, R.I. and Sutherland, G. R. (1992). Dynamic Mutations Causing Human Disease. Cell, 70:709-712.

6. Caskey, C.T., Pizzuti, A., Fu, Y-H., Fenwick, R.G. and Nelson, D.L. (1992). Triplet Repeat Mutations in Human Disease. Science, 256:784-789.

7. Wooster, R., Cleton-Janse, A.-M., Collins, N., Mangion, J., Cornelis, R.S., Cooper, C.S., Gusterson, B.A., Ponder, B.A.J., von Deimling, A., Wiestler, O.D., Cornelisse, C.J., Devilee, P. and Stratton, M.R., (1994) Instability of Short Tandem Repeats (microsatellites) in human cancers. Nature Genetics, 6:152-156.

8. Chen, X., Mariappan, S.V.S., Catasti, P., Ratliff, R., Moyzis, R.K., Laayoun, A., Smith, S.S., Bradbury, E.M., and Gupta, G. (1995). Hairpins are formed by the single DNA strands of the Fragile X Triplet Repeats: Structure and Biological Implications.

Proc. Natl.Acad. Sci. USA 92:5199-5203.

9. Mariappan, S.V.S., Chen, X., Catasti, P., Ratliff, R., Moyzis, R.K., Bradbury, E.M., and Gupta, G. (1996). Solution Structure of the Individual Strands of the Fragile X repeat. Nucl. Acid Res. 24:784-792. 
10. Hairpin and junction structures of fragile $X$ triplets. Mariappan, S.V.S., Chen, X., Catasti, P., Ratliff, R., Moyzis, R.K., Laayoun, A., Smith, S.S., Bradbury, E.M., and Gupta, G. Biol. Str. \& Dyn. Proc. of the 9 th Conversation in Biomol. Stereodyn., SUNY at Albany, NY 1995, Eds. Sarma, R.H. and Sarma, M.H., Adenine press, pp 105119.

11. Chen, X., Mariappan, S.V.S., Moyzis, R.K., Bradbury, E.M. and Gupta. G. (1997). Hairpin Induced Slippage and Methylation of the Fragile X Repeats. J. Biomol. Str. \& Dyn., submitted.

12. Mariappan, S.V.S., Cehn, X., Ratliff, R., Moyzis, R.K., Garcia, A.E., Bradbury, E.M., and Gupta, G. (1997). Solution Structure of the DNA Triplet, CAG, Associated with Hunitington's Disease. Biochemistry, submitted.

13. Catasti, P., Chen, X., Moyzis, R.K., Bradbury, E.M., and Gutpa, G. (1996). Structure-function correlations of the insulin-linked polymorphic region. J. Mol. Biol. 264:534-545.

14. Catasti, P., Chen, X., Bradbury, E.M., and Gutpa, G. (1997). The G-rich strand of the insulin-minisatellite forms a hairpin G-quartet structure in solution. Biophys. Jl. to be submitted.

15. Catasti, P., Chen, X., Moyzis, R.K., Bradbury, E.M., and Gutpa, G. (1997). Solution Structure of the C-rich Strand of the Insulin Mini-Satellite. J. Mol. Biol. to be submitted.

16. Pieretti, M., Zhang, F., Fu, Y.-H., Warren, S.T., Oostra, B.A., Caskey, C.T., and Nelson, D.L. (1991) Absence of expression of the FMR-1 gene in fragile X syndrome. Cell 66, 817-822.

17. Meehen, R. R., Lewis, J.D., McKay, S. Kleiner, E.L. and Bird, A. (1989) Identification of a Mammalian Protein that binds specifically to DNA Contiaining Methylated CpGs. Cell 58:499-507. 


\section{INSET}

Hairpin Models for
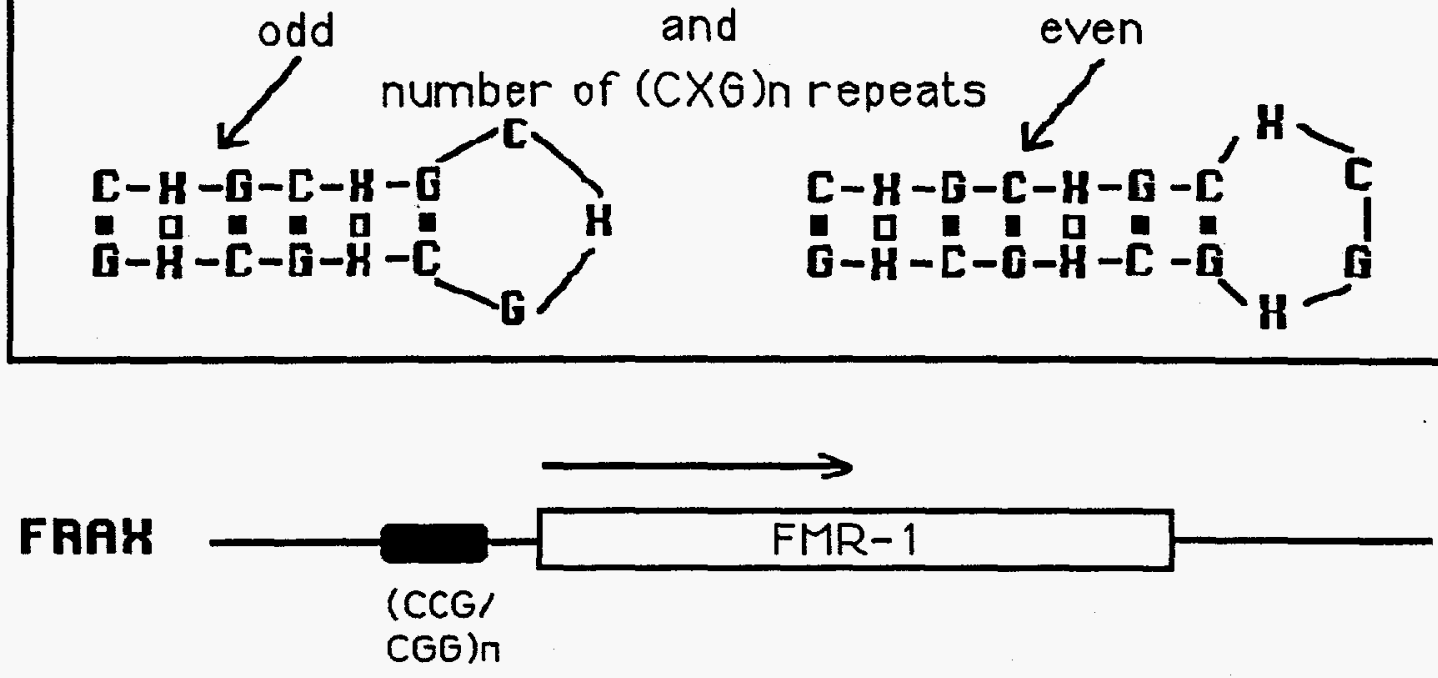

$D M$

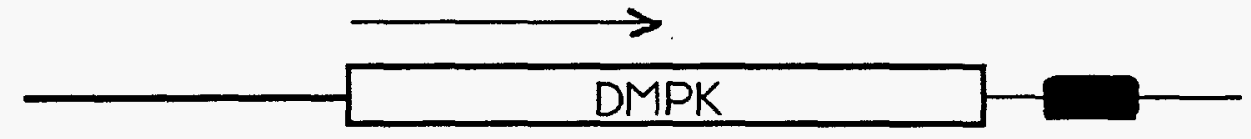

(CTG)n

HD

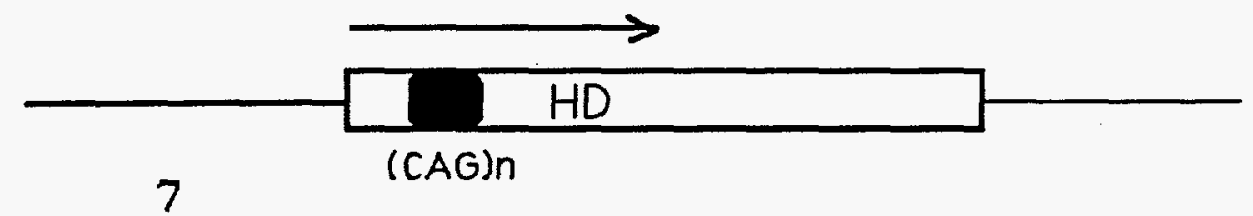

Figure 1 Locations of the (CXG) triplet repeats with respect to the associated genes (adapted from ref. 7). For each triplet repeat the repeat length $(n)$ distiguishes three different alleles: normal $(N)$, transmitting $(T)$, and disease (D) phenotypes. In FraX, $n=6-50$ for $N, n=51-200$ for $T$, and $n>200$ for $D$. In $D M, n=5-27$ for $N, n=28-50$ for $T$, and $n>50$ for $D$. In $H D, n=13-30$ for $N, n=31-39$ for $T$, and $n>39$ for $D$. Our structural studies [13-17] show that Frax, DM, and HD triplets can form hairpin structures for both odd and even number of repeats. As shown in the (INSET) purine.purine or pyrimidine.pyrimidine mispairs are present in the stem. 


\section{Effect of Expansion and Methylation of the Fragile $X$ Repeat}

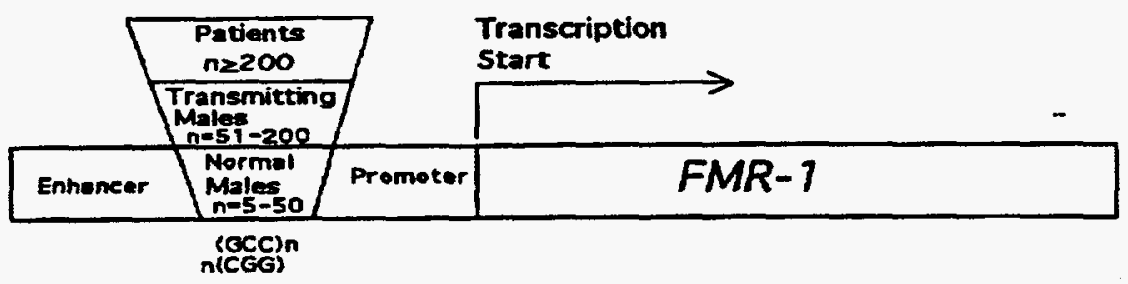

\section{Control}

Region

Methylation

Normal

Expanded

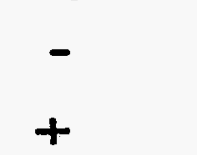

INSET

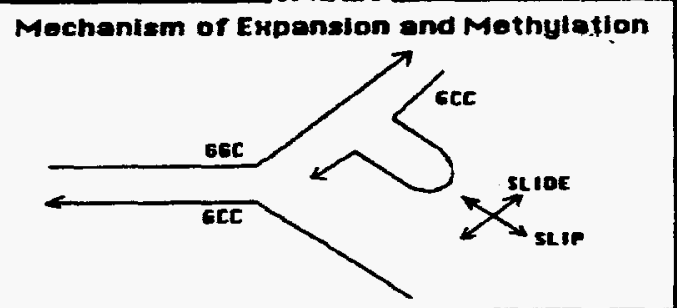

Transcription of FMR-1

Figure 2 A schematic representation of the FMR-1 gene [7-8]. The location of the fragile $X$ repeat, $(G C C)_{n} \cdot(G G C)_{n}$, is shown in the $5^{\prime}$ untranslated region although the exact location and the inter-relationship of the promorer and the enhancer are not yet known. The ranges of repeat numbers, $n$, are shown for normal, transmitting, and affected males. Therefore, from normal to affected males, the control region undergoes a transition from low density CpG to high density $C p G$ island due to the massive expansion [28-30] and the subsequent methylation of the fragile $X$ repeat. The high density methylated CpG sites attract strong methyl binding proteins [31] that cannot be dissociated by transcription activator proteins or RNA polymerase and this leads to the suppression of the FMR-I gene. INSET A sketch of how the presence of the transient and mobile three-way junction can cause both expansion and methylation. The intrinsic preference of hairpin formation by the GCC-strand leads to a three-way junction with a Watson-Crick anchor. When the GGC-strand acts as the template, such a three-way junction leads to expansion if the GCC hairpin escapes repair. These three-way junctions are also excellent substrates for CPG methylation by the human methyltransferase. 